\title{
THE EFFECT OF COMPANY SIZE, PROFITABILITY, LEVERAGE, AND MANAGEMENT OWNERSHIP TOWARDS THE LEVEL OF CORPORATE SOCIAL RESPONSIBILITY (CSR) DISCLOSURE
}

\author{
Jacqueline Vania Wardhani ${ }^{1}$, Luky Patricia Widianingsih ${ }^{2}$, \\ Frandy Karundeng ${ }^{3}$ \\ Universitas Pelita Harapan ${ }^{1}$, Universitas Ciputra Surabaya ${ }^{2}$, \\ Universitas Pelita Harapan ${ }^{3}$
}

\begin{abstract}
The Government has regulated CSR activities through Law No. 40 Year 2007 regarding Limited Liability Company. Mentioned that the company must perform and disclose CSR activities, especially companies that related to natural resources such as mining companies. The objective is to know the effect of company size, profitability, leverage, and management ownership on the level of CSR disclosure of mining companies listed on BEI during the period of 2014-2017. Using secondary data from annual report and financial report. The samples sum up to a total of ten companies with a four-year observation period, resulting in a total of 40 observational data. The method used in this research is multiple linear regression using SPSS 22.0 program. The result of the research shows that (1) firm size has positive effect on CSR disclosure level, (2) profitability and leverage has no effect on CSR disclosure level; (3) management ownership negatively affect CSR disclosure level. This finding contributes to the future research, companies, creditors, investors, and government.
\end{abstract}

Keywords: firm size, profitability, leverage, management ownership, csr disclosure level, mining companies.

\section{INTRODUCTION}

A company is an organization that produces goods and/ or services to fulfil the needs of the community by seeking and using production factors and aims to earn profits (Wasis, 1997). The activities of seeking and using production

\footnotetext{
*Corresponding Author.

e-mail: vania.jacqueline97@gmail.com
} 
factors can also be referred to as operational activities of the company. Companies must be able to manage their resources well, such as managing and developing their assets, managing capital to generate profits, having strict policies in the use of debt to fund company capital, and managing capital obtained from the sale of good shares to external and internal parties of the companies. It is important for the company to be able to compete well so that the company's going concern goals can be achieved. Another goal that the company must fulfil is related to sustainability, where in this set of goal, the objectives include the concept of triple-bottom line, namely profit, people and planet. This concept states that companies should not only pay attention to the profits that the company will obtain, but also to other two important aspects, namely the human (people) and the environment (planet). The triple-bottom line concept underlies the company's Corporate Social Responsibility (CSR) activities. According to Vogel (2005), Corporate Social Responsibility is activities carried out by the companies that are related to the company virtues, where these activities represent the company's effort to do more in overcoming social problems that in pursuing profits.

The Corporate Social Responsibility program is carried out by the companies to bring harmonization between the companies and the stakeholder, because companies are not only required to maximize the company's profit but also the role of stakeholder (Agustina et al., 2015). Caroll (2015) defined socially responsible companies as those who made more efforts to integrate its attention to other stakeholders in its policies, decision making, and operations. The conclusion of some of these opinions is that Corporate Social Responsibility programs do not only function as fulfilling people's expectation, but also as a form of corporate responsibility to the stakeholders they have. The companies show that they are not only responsible for seeking profits and obeying the law alone, but also responsible for conducting charity activities.

Another factor that causes companies to do and disclose CSR is the existence of Indonesian Law No. 40 of 2007 concerning Limited Liability Companies. In the law, it is clearly written that companies are obliged to carry out social and environmental responsibility activities and are obliged to report these activities in annual reports made by the company, especially for companies whose business activities are related to natural resources, for example mining 
companies. According to the Jaringan Advokasi Tambang (JATAM) in Bangkapos.com (2012), around $70 \%$ of the damage to the environment in Indonesia is the result of mining operations and almost 34 percent of Indonesia's land mass is left to mineral and coal mining companies.

In other cases, the case of oil pipeline leakage from PT. Pertamina, which is located in Balikpapan Bay, East Kalimantan also caused fire and deaths of five people and one rare marine mammal, Pesut, 162 fishing boats and fishing gear could not be used to sail due to contamination of the crude oil, and the closure of Semayang Port, which resulted in sips arriving in Balikpapan unable to enter and lean on ports and ships in Balikpapan Bay cannot get out of the port (Antara, 2018; Ihsanuddin, 2018; Primadhyta, 2018; Ramadhani, 2018). Poisoning cases caused by several coal mines on the island of South Kalimantan has also caused water damage and endangered the health and the future of the local community.

Sriayu \& Mimba (2013) and Dewi \& Priyoni (2013) revealed that company size is a certain scale used to measure the size of the company. Company size is often used as an independent variable that is used to explain variations in disclosure of company annual reports, including disclosure of CSR. Leverage is a measuring instrument used to measure the company's capacity or ability to pay all debts held. The level of leverage of a company can describe the financial risks held by the company (Maulana \& Yuyetta, 2014; Sembiring, 2005). Nazir et al. (2014) expressed that profitability is a measure used to measure the ability of corporate executives to create a level of profit for the company. This level of profit can be used as a consideration for the company to design, conduct and report on social and environmental programs. Management ownership is the ownership of shares by the management of the company, which is described using a percentage of the shares held by the management. It is intended that management has a sense of belonging to the company that makes management work as well and as much as possible so that the companies they own can provide benefits to the company (Sujono \& Soebiantoro, 2007) in (Subiantoro \& Mildawati, 2015).

Previous researches conducted by Subiantoro \& Mildawati (2015), and Manurung \& Muid (2015), resulted in a conclusion that company size does not significantly influence the level of CSR disclosure, while researches conducted by Yuliawati \& Sukirman (2015), Maulana \& Yuyetta (2014), Sriayu \& Mimba 
(2013), and Dewi \& Priyadi (2013) show that company size significantly affects the level of CSR disclosure. Another researches by Subiantoro \& Mildawati (2015), Manurung \& Muid (2015), Maulana \& Yuyetta (2014), Sriayu \& Mimba (2013), and Dewi \& Priyadi (2013) shows that profitability does not significantly affects the level of CSR disclosure, while researches conducted by Istifaroh \& Subardjo (2017) and Yuliawati \& Sukirman (2015) concludes that profitability show a significant effect to the level of CSR disclosure. Another researches conducted by Subiantoro \& Mildawati (2015), and Manurung \& Muid (2015), Maulana \& Yuyetta (2014), Sriayu \& Mimba (2013), and Dewi \& Priyadi (2013) found that leverage does not have a significant affect towards CSR disclosure, while researches by Istifaroh \& Subardjo (2017) and Yuliawati \& Sukirman (2015) found that leverage have a significant affects towards CSR disclosure. Past researches conducted by Subiantoro \& Mildawati (2015) reveal that management ownership did not significantly affects the level of CSR disclosure, whereas the research conducted by Dewi \& Priyadi (2013) shows that management ownership significantly affects the level of CSR disclosure.

The variation of findings on past studies attract the researcher to re-examine in order to find out whether company size, profitability, leverage, and management ownership affect the level of CSR disclosure of mining companies in Indonesia. This reason has led the researchers to conduct a study entitled "The Effect of Company Size, Profitability, Leverage, and Management Ownership towards the Level of Disclosure of Corporate Social Responsibility (CSR).” The hypotheses are as follow:

Hypothesis 1: Company size affects the level of CSR disclosure.

Hypothesis 2: Profitability affects the level of CSR disclosure.

Hypothesis 3: Leverage affects the level of CSR disclosure.

Hypothesis 4: Management ownership affect the level of CSR disclosure.

\section{METHOD}

\section{Population and Sample}

The research population includes all mining companies in Indonesia. The sampling technique is based on the purposive sampling method. The criteria used in this study include: 
1. The mining companies are consecutively listed on the IDX in the 2014-2017 period.

2. The companies always published their financial reports and annual reports in the 2014-2017 period on the IDX website or the company's official website.

3. The companies' financial statements show profits.

4. The companies provide all information needed to measure the research variables.

Data collection is completed using the documentation study technique. The data used and collected in this study is the secondary data. Secondary data used are mainly the annual reports and financial reports issued by mining companies listed on the IDX, so that both reports can be downloaded through the official IDX website and/ or the official website of each company.

\section{Operational Definition and Variable Measurement}

Independent Variable of Company Size (SIZE)

The company size is used to determine how big or how small a company is. Researches conducted by Yuliawati \& Sukirman (2015), Manurung \&Muid (2015), Subiantoro \& Mildawati (2015), Maulana \&Yuyetta (2014), Dewi \&Priyadi (2013), Sriayu \& Mimba (2013) and Wang et al. (2013) consistently use the total of company assets that is transformed in natural logarithms to measure a company size. Asset value is used because mining companies are capital intensive companies, namely companies that dominantly operates based on the assets and not labor. The value of company assets is transformed into natural logarithms; hence the value is the same as the other variables, especially because total assets have a relatively large value when being compared with other variables in this study.

SIZE: $\log _{\mathrm{n}}$ Total Company Asset

\section{Independent Variable of Profitability (ROE)}

According to Sriayu \& Mimba (2013) and Yuliawati \& Sukirman (2015), company's profitability can be measured using a measure of ROE (Return on Equity). ROE is the percentage of profits obtained using equity owned by the 
company. ROE is the most comprehensive indicator to measure a company's profitability, because ROE is the end result of all activities and decisions made by the company during the year. ROE considers operating and investment decision as well as considering decisions related to funding and corporate taxation (Hawawini \& Viallet, 2007). In this study, the ROE is obtained from the Financial Highlights or the Financial Overview of the Company in the company's annual report. There are several terms (other than ROE) used by companies, namely:

1. Income to equity ratio

2. Return on equity

3. Net profit/total equity

4. Net profit to equity

5. Net income to equity

6. Ratio of net income to equity

\section{Independent Variable of Debt to Equity Ratio (DER)}

Leverage owned by the company shows the company's funding structure, namely how much the company's debt is in funding its operating activities. The DER figure used in this study is obtained from the Financial Data Highlights or Financial Overview of Companies section of the company's annual report.

\section{Independent Variable of Management Ownership (KM)}

Management ownership is the percentage or the proportion of share ownership by company management (Subiantoro \& Mildawati, 2015; Dewi \& Priyadi, 2013). Management ownerships, as a variable in this study, will be reviewed from the company's annual report on the shareholder information or share information or composition of shareholders, with the term of share ownership by directors and commissioners.

\section{Dependent Variable: Company's CSR Disclosure}

The dependent variable in this study is the level of company's CSR disclosure. The level of CSR disclosure is measured using the Corporate Social 
Responsibility Disclosure Index (CSRDIj). According to the research of Manarung \& Muid (2015), Oktariani (2013), CSRDIj is measured using a checklist based on the GRI G4 indicator and divided into 91 disclosure items. Each CSR disclosure item checklist disclosed in the company's annual report will be given a score of 1 an if not disclosed then will be given a score of 0 . The measurement of CSRDI will be carried out using the following formula (Dewi and Priyadi, 2013; Sembiring, 2005).

$$
\operatorname{CSRDIj}=\frac{\sum \mathrm{xij}}{\mathrm{nj}}
$$

History:

CSRDIj $=$ Corporate Social Responsibility Disclosure of Company J

$\mathrm{Xij}=$ Number of items disclosed by Company $\mathrm{J}$, if disclosed then given a score of 1 , if it is not disclosed then a score of 0 will be given, so $0 \leq \mathrm{CSRDI} \leq 1$

$\mathrm{nj}=$ Number of disclosure items for Company $\mathrm{J}, \mathrm{nj} \leq 91$

\section{Data Analysis Method}

This stage is being completed in several stages as follows: Descriptive Statistics, Classical Assumption Test and Multiple Linear Regression Analysis. While the Model Feasibility Test is done through F-Statistic Test, Adjustment Coefficient Test (Adjusted $\mathrm{R}^{2}$ ) and Hypothesis test.

\section{RESULTS}

The number of mining companies that are listed on the Indonesian Stock Exchange in the 2014-2017 period are 40 companies. Three out of the 40 companies did not issue financial reports and annual reports in the study period, leaving the remaining 37 companies. As many as 18 out of the 37 companies did not get a profit, so there were 19 companies remain. After further selection, nine out of 19 companies did not disclose share ownership by the management, hence the remaining 10 companies will be used as the research samples. Of the 10 sample companies that have been selected, it will be multiplied by four years of observation; so, a total of 40 reports will be used in the study. Table 1 shows the data of research sampling. 
Table 1 Research Sample

\begin{tabular}{clc}
\hline No. & \multicolumn{1}{c}{ Criteria } & Total \\
\hline 1 & The company is registered in the IDX during the 2014-2017 period & 40 \\
2 & The company does not con issue their financial report and annual & $(3)$ \\
& reportin a row in the 2014-2017 period & \\
3 & The company does not get profits & $(18)$ \\
4 & The company does not provide information about share ownership \\
by thecompany management & (9) \\
Total Sample & $\mathbf{1 0}$ \\
\hline
\end{tabular}

Out of the then companies selected as the research samples, there are four companies that have abnormally distributed data, namely: (a) PT Baramulti Sukessarana Tbk, (b) PT Citatah Tbk, (c) PT Surya Esa Perkasa Tbk, and (d) PT Timah Tbk. The four companies were then removed from the list of sample group. Hence, the remaining six companies will be used as the sample of the study. The six companies will be multiplied by four years of observation; so, a total of 24 reports will be used in this study. The list of mining companies sampled in the study can be seen from Table 2 .

Table 2 List of Sample of Mining Companies Participated in the Research

\begin{tabular}{ccl}
\hline No. & Stock Code & \multicolumn{1}{c}{ Company Name } \\
\hline 1 & ADRO & PT Adaro Energy Tbk \\
2 & GEMS & PT Golden Energy Mines Tbk \\
3 & ITMG & PT Indo Tambangraya Megah Tbk \\
4 & KKGI & PT Resource Alam Indonesia Tbk \\
5 & TOBA & PT Toba Bara Sejahtera Tbk \\
6 & ARTI & PT Ratu Prabu Energi Tbk \\
\hline
\end{tabular}

\section{Descriptive Statistic of Research Variables}

Descriptive statistic from the research data is stated in Table 3, where in total there are 24 total observations. Of the 24 observations, the variable of company size (SIZE), that is proxied using the amount of company assets (in US Dollar units) has an average of $1,446,705,905$. This means that in average, the company in Indonesia has assets of $\$ 1,446,705,905$. The minimum value of the SIZE variable is $\$ 98,541,575$ owned by PT Resource Alam Indonesia Tbk. The biggest value of the SIZE variable is $\$ 6,814,147,000$ owned by PT Adaro Energy 
Tbk. Based on Table 3, it also can be seen that there is a fairly high difference between the average value and the maximum value of the company size. The huge gap is present because PT Adaro Energy Tbk have a very high number of company assets compared to the other five companies.

Table 3 Descriptive Statistic of Research Variables

\begin{tabular}{ccccc}
\hline Variable & $\mathbf{N}$ & Minimum & Maximum & Average \\
\hline SIZE & 24 & $98,541,575$ & $6,814,147,000$ & $1,446,705,905$ \\
ROE & 24 & 0.01000 & 0.40760 & 0.1219667 \\
DER & 24 & 0.10200 & 1.10000 & 0.5441917 \\
KM & 24 & 0.00000 & 0.15190 & 0.00249950 \\
CSRDIj & 24 & 0.05495 & 0.39560 & 0.1327839 \\
\hline
\end{tabular}

The variable of profitability (ROE) that is proxied using the Return on Equity number has an average value of 0.1219667 or $12.20 \%$. This percentage shows that in mining companies in Indonesia, on average every US $\$ 1$ of shareholder equity an generate profits of US $\$ 0.122$. the minimum value of ROE is 0.01000 or $1 \%$, which is owned by PT Ratu Prabu Energi Tbk. The maximum value of ROE is 0.40760 or 40.76\% and is owned by PT Golden Energy Mines Tbk.

The leverage variable (DER) is proxied using the Debt to Equity Ratio and shows an average value of 0.5441917 or $54.42 \%$. From this percentage, it can be seen that he average amount of equity of the mining companies in Indonesia financed by debt is $54.42 \%$. the minimum value of DER is 0.10200 or $10.2 \%$ owned by PT Golden Energy Mines Tbk. The maximum value of DER is 1.10000 or $110 \%$ and is owned by PT Toba Bara Sejahtera Tbk.

Management ownership variable (KM) which is measured using the number of share ownership by the management of the company has an average value of 0.00249950 or $0.25 \%$. This percentage shows that the average management of share ownership in mining companies in Indonesia is $0.25 \%$. The minimum value of KM is 0.00000 or $0 \%$, owned by PT Toba Bara Sejahtera Tbk. The maximum value is owned by PT Adaro Energy Tbk with a value of 0.14190 or $15.19 \%$. It can be seen that KM variable shows a high range between the average value and the maximum value. The range exist due to PT Adaro Energy Tbk having a high level of share ownership by management compared to the other five sample companies. 
The variable of CSR disclosure (CSRDIj) measured using the CSR disclosure index based on the GRI G4 standard has an average of 0.1327839 or $13.28 \%$. This number means that on average, mining company in Indonesia only discloses $13.28 \%$ if it is adjusted to the GRI G4 standard. The minimum value of CSRDIj variable is 0.05495 or $5.50 \%$, which is owned by PT Ratu Prabu Energi Tbk. The maximum value of CSRDIj is 0.39560 or $39.56 \%$ that is owned by PT Indo Tambangraya Megah Tbk. The value of CSRDIj also shows a big range between the average value and the maximum value. This is due to the different standards that can be used by each company in disclosing CSR, so companies that use the GRI standard will have a much higher of disclosure compared to other companies that use other disclosure standard.

\section{Data Quality Test}

The normality test shown in Table 4 shows that the significance value of all the independent and dependent variables in the study is higher than the value of á of 0,05 , so it can be concluded that all variables used in this study are normally distributed. The multicollinearity test result that is shown in Table 5 states that all independent variables have a tolerance value of greater than 0.1 and VIF of less than 10. These results indicate that there is no multicollinearity issue within the study. In addition, the heteroscedasticity test result shown in Table 6 states that the significance value of all independent variables is more than $5 \%$. The significant values that exceed 0.05 indicate that there is no issue of heteroscedasticity within the independent variable of the study. While the results of the Autocorrelation test in Table 7 shows the value of $\mathrm{du}<\mathrm{d}<4$-di. The value of $\mathrm{du}$ is obtained from the DW table at the level of $\alpha$ of $5 \%$, the four independent variables $(\mathrm{k})$ and 24 research samples (n). The results indicate that there is no issue related to autocorrelation in this study.

Table 4 Result of Normality Test Using Kolmogorov-Smirnov

\begin{tabular}{lcc}
\hline & Significance & Explanation \\
\hline Unstandardized Residual & 0,200 & Normal Distribution \\
\hline
\end{tabular}


Jacqueline Vania Wardhani, Luky Patricia Widianingsih, Frandy Karundeng / The Effect of Company Size, Profitability, Leverage, and Management Ownership towards the Level of CSR Disclosure

Table 5 Result of Multicollinearities Test Using Tolerance Value and VIF

\begin{tabular}{|c|c|c|c|c|}
\hline Variable & Tolerance & VIF & Result & \\
\hline Ln_SIZE & 0,289 & 3,458 & There is multicollinearity & no \\
\hline $\mathrm{ROE}$ & 0,753 & 1,328 & There is multicollinearity & no \\
\hline DER & 0,822 & 1,217 & There is multicollinearity & no \\
\hline $\mathrm{KM}$ & 0,257 & 3,898 & There is multicollinearity & no \\
\hline
\end{tabular}

Table 6 Result of Heteroskedasticities Test Using Park test

\begin{tabular}{lccc}
\hline Variable & Significance & Result & \\
\hline Ln_SIZE & 0,579 & There is heteroskedasticities & no \\
ROE & 0,769 & There is heteroskedasticities & no \\
DER & 0,120 & There is heteroskedasticities & no \\
KM & 0,462 & There is heteroskedasticities & no \\
\hline
\end{tabular}

Table 7 Result of Autocorrelation using Durbin-Watson

\begin{tabular}{ccccc}
\hline Model & du & Durbin-Watson(d) & 4-du & Result \\
\hline 1 & 1,775 & 2,016 & 2,225 & No correlation present \\
\hline
\end{tabular}

\section{Multiple Linear Regression Method}

Based on the multiple linear regression method that has been done, the multiple linear regression equation in this study can be arranged as follows.

CSRDIj $=1,350$ SIZE $-0,059 \mathrm{ROE}-0,171 \mathrm{DER}-1,106 \mathrm{KM}+\mathrm{e}$

\section{Model Feasibility Test}

According to Table 8 that shows the result of F-statistic test, the significance value obtained in the study is less than 0.05 , which is equal to 0.000 . From the significance value, it is known that there is at least one independent variable that has an influence on the dependent variable, so that the research model is feasible to be continued further. Meanwhile, the result of the Coefficient of Determination test (Adjusted R2) resulted with a value of 0,584 and is shown in Table 9. The adjusted R2 means that the independent variables used in this study are able to explain the dependent variable by 58,84\%. Meanwhile, the remaining $41,6 \%$ is explained by other independent variables that are not discussed in this study. 
Table 8 Result of the F-statistic Test

\begin{tabular}{lccccc}
\hline \multicolumn{1}{c}{ Model } & $\begin{array}{c}\text { Sum of } \\
\text { Squares }\end{array}$ & df & $\begin{array}{c}\text { Mean } \\
\text { Square }\end{array}$ & F-statistic & Sig \\
\hline Regression & 0,138 & 4 & 0,035 & 9,06 & 0 \\
Residual & 0,073 & 19 & 0,004 & & \\
Total & 0,211 & 23 & & & \\
\hline
\end{tabular}

Table 9 Result of Determination Coefficient (Adjusted $\mathbf{R}^{2}$ )

\begin{tabular}{ccccc}
\hline Model & $\mathbf{R}$ & R Square & $\begin{array}{c}\text { Adjusted } \\
\text { RSquare }\end{array}$ & $\begin{array}{c}\text { Std. Error of } \\
\text { the Estimate }\end{array}$ \\
\hline 1 & 0,810 & 0,656 & 0,584 & 0,06177818 \\
\hline
\end{tabular}

\section{Hypothesis Testing}

According to Table 10, it can be seen that the SIZE variable (Company Size) has a significance value of less than 0,05 , which is equal to 0,000 . This value shows that the SIZE variable has an influence of the level of CSR disclosure. The beta coefficient value of the SIZE variable shows a positive value; hence, it can be seen that the SIZE variables have a positive effect on the level of CSR disclosure in mining companies in Indonesia.

Table 10 Result of the Research Hypothesis using t-statistic Test

\begin{tabular}{lccc}
\hline \multicolumn{1}{c}{ Model } & $\begin{array}{c}\text { Coefficient } \\
\text { Beta }\end{array}$ & t-Statistic & Significance \\
\hline Constanta & & $-4,963$ & 0,000 \\
Ln_SIZE & 1,350 & 5,394 & 0,000 \\
ROE & $-0,059$ & $-0,381$ & 0,708 \\
DER & $-0,171$ & $-1,150$ & 0,264 \\
KM & $-1,106$ & $-4,163$ & 0,001 \\
\hline
\end{tabular}

ROE variable (Profitability) has a significance value of greater than 0,05 , which is 0,708 . This value indicate that the ROE variable does not affect the level of CSR disclosure in mining companies in Indonesia. DER variable (Leverage) also has a significance value of greater than 0,05 , which is 0.264 . This value indicates that the DER variable does not affect the level of CSR disclosure in mining companies in Indonesia. 
The variable of KM (Management Ownership) has a significance value of less than 0,05 , which is 0,001 . This value shows that $\mathrm{KM}$ has an effect towards CSR disclosure. The beta coefficient value of the KM variable shows a negative value. So, it can be concluded that KM has a negative effect on the level of CSR disclosure in mining companies in Indonesia.

\section{DISCUSSION}

\section{The Effect of Company Size towards the Level of CSR Disclosure}

Based on the statistical test that has been conducted, it is found that the size of the company has a positive effect on the level of CSR disclosure. The bigger the size of the company, the higher the level of CSR disclosure by the company. Large companies will get a lot of attention and recognition from the government and the society, so that the shareholders are willing to pay more attention to their CSR programs that are carried out and disclosed. Large size companies are considered to have a greater risk of creating environmental damage compared to the smaller companies. With the attention from various parties, the company will act more careful and increasingly show concern for the environment in order to build a good image in the community (Dewi \& Priyadi, 2013).

This finding supports the legitimacy theory and agency theory. According to Yuliawati \& Sukirman (2014), large-sized companies must try to gain the legitimacy from the community because the bigger company is, the more people will be involved in the company's operational actions. According to the agency theory, the larger the company, the greater the costs that must be incurred. This causes companies to provide more and more information to reduce agency costs (Sembiring, 2005).

The highest level of CSR disclosure among all of the research samples is owned by PT Indo Tambangraya Meggah Tbk with a total disclosure of 35 items, 30 items, 25 item, and 31 items in consecutive within the study period. The company became one of the companies with the largest number of assets compared to other research samples. The acceptance of the first hypothesis of this study is supported by several past studies conducted by Yuliawati \& Sukirman (2015), Maulana \& Yuyetta (2014), Sriayu \& Mimba (2013), Dewi \& 
Priyadi (2013) and Sembiring (2005). The five studies agree that the size of a company will have an effect on the level of CSR disclosure carried out by each company.

However, this study does not support researches conducted by Subiantoro \& Mildawati (2015) and Manurung \& Muid (2015). Both studies stated that company size does not affect the level of CSR disclosure. Their reasoning is that companies will conduct CSR and disclose only if the company has a concern and sensitivity to environmental and social factors around the company, and not because whether the company size is big or small.

\section{The Effect of Profitability towards the Level of CSR Disclosure}

Based on the statistical test that has been conducted, it is known that profitability does not affect the level of CSR disclosure. According to Subiantoro \& Mildawati (2015), when a company generates profits, thus the company will maximize its profits for the benefit of the company's operational activities. Maximizing their operational activities is seen as providing more benefits to the company for the upcoming period and for the company's shareholder.

Another factor that supports the fact that profitability does not affect CSR disclosure is because at the beginning of the study period, there was a decline in the world's mining prices and demand for mining materials from China. Both of these factors have a detrimental effect on profitability generated by mining companies. In fact, some mining companies suffered losses at the beginning of the period. The decline in the study sample company's profits can be seen at Table 12. The condition of mining companies that are not as good as this makes the company focus on saving costs to maintain the survival the company. Hence, there are limited number of CSR activities that are carried out and disclosed by the company (Gewati, 2016; Rembeth, 2016; Dianjiwa, 2015).

The low profitability and the low level of CSR disclosure of mining company in the study period can be proven from the low ROE rate the level of CSR disclosure of PT Ratu Prabu Energi bk. In 2014. In 2014, the company's ROE rate reached 3\%, but in the following years until 2017, the company's ROE figure only reached $1 \%$. The level of CSR disclosure only reached six indicators compared to 91 indicators in 2014-2016 and five out of the 91 indicators on 
2017. Similar findings were found in other studies conducted by Sembiring (2015), Manurung \& Muid (2015), Subiantoro \& Mildawati (2015), Maulana \& Yuyetta (2014), Sriayu \& Mimba (2013), and Dewi \& Priyadi (2013). These seven studies agree that profitability does not affect the level of CSR disclosure because when profitability figures are high, companies do not want to disrupt financial success with other information. In addition, the profits obtained by the company will be maximized for its operational activities.

On the other hand, this research does not support other findings from Istifaroh \& Subardjo (2017) and Yuliawati \& Sukirman (2015). Both researches agree that profitability has a positive effect on the of level of CSR disclosure. This is due companies with high profitability will be more demanded by their stakeholders to carry out and disclose CSR as an adequate source of information for stakeholders.

\section{The Effect of Leverage Towards the Level of CSR Disclosure}

According to the statistical test that has been conducted, the result shows that leverage does not affect the level of CSR disclosure. Leverage does not affect the CSR disclosure because the company will use funds obtained from loan to support its internal activities, where the majority of which are activities to increase the company's production. These activities are carried out to increase the value and the quality of production, so that the company can develops. The loan obtained by the company is not used to carry out CSR activities and CSR disclosures.

Subiantoro \& Mildawati (2015), Maulana \& Yuyetta (2014), Dewi \& Priyadi (2013) and Sriayu \& Mimba (2013) stated that CSR activities and the disclosures will also be carried out by companies as a form of company compliance with regulations set by the government. CSR activities and disclosures are not things that are voluntarily carried out by the company but are an obligation that must be carried out by the company. The obligation to carry out CSR disclosures is considered as increasing the positive image of the company in its surrounding environment. Companies that show attention to the surrounding environment will also make every effort to carry out CSR activities and disclose them without seeing how much debt they have. 
The fact that leverage does not affect the level of CSR disclosure can be proven from the amount of debt proxied using the DER number and the level of CSR disclosure in PT Toba Bara Sejahtera Tbk. The DER value of PT Toba Bara Sejahtera Tbk shows the highest number of DER value during the study period when being compared to other companies of the research samples. Even the number had decreased from 110\% in 2014 to $80 \%$ in 2015 and 2016, then increased again to $100 \%$ in 2017 . While the level of disclosure of company's CSR disclosure remined table at 8 out of 91 disclosures. The result of this study in in line with researches conducted by Sembiring (2015), Manurung \& Muid (2015), Subiantoro \&Mildawati (2015), Maulana \& Yuyetta (2014), Sriayu \& Mimba (2013), and Dewi \& Priyadi (2013). The six studies agreed that leverage does not affect the level of company's CSR disclosure because CSR disclosure is carried out as a form of compliance with the government regulations as well as a form of sensitivity to the surrounding environment.

This finding is not in line with a research conducted by Istifaroh \& Subardjo (2017). The study revealed that leverage has a positive effect towards the level of CSR disclosure. I stated that companies with higher debt level will tend to disclose CSR information as widely as possible for the means of meeting the information needs of creditors. Disclosure of CSR made the company looks more credible and convinced the creditors to provide loans.

\section{The Effect of Management Ownership towards the Level of CSR Disclosure}

Based on statistical test that has been conducted, the result shows that management ownership negatively affects the level of CSR disclosure. This is due to a conflict of interest that follows the management role as the owner of the company. Managers of the company that share ownership will focus on maximizing the profits they can get at the end of the year. The way that can be used to maximize profits is by pressing the load number. Thus, the company manager will try to reduce the funds spent on CSR activities and disclosure.

It is inversely proportional to the small percentage of management ownership. When the share is owned by a small company, then the management will maximize its role as a manager of the company. When the company manager maximizes their role as a manager, they will tend to maximize the potential of 
the company to provide a good image in the community. The trick is to do as many CSR activities as possible and disclose every activity (Gray \& Maunders in Dewi \& Priyadi, 2013).

PT Ratu Pracbu Energi Tbk is a company with the lowest disclosure rate compared to the other sample companies, which only shows six out of 91 disclosure items in 2014-2016 and five out of 91 disclosure items in 2017. With a low level of CSR disclosure, PT Ratu Pracbu Energi Tbk have a higher percentage of management ownership compared to the other sample population. The percentage of management ownership held by PT Ratu Pracbu Energi Tbk in 2014 to 2017 was, respectively, $1.62 \%, 0.32 \%, 0.37 \%$, and $0.32 \%$. The results of this study show similarities to a previous study conducted by Dewi \& Priyadi (2013). The study states that management ownership has a negative effect on CSR disclosure because a small amount of management ownership will create a better process of monitoring, so that the company management can provide the whole information to the stakeholders. A high number of management ownership will cause the emergence of a conflict of interest between the manager and the owner so that the manager will maximize his own interest.

On the other hand, the result of this study does not support a past study conducted by Subiantoro \& Mildawati (2015). The study shows that management ownership has no effect on CSR disclosure. This may happen because the company's management can easily obtain and access information about the company's CSR activities, so there is no need to wait for the company to publish their annual reports or company sustainability reports. Information about the company's CSR activities will be disclosed as needed and not as detailed as possible.

\section{Conclusion}

Company size has a positive effect on CSR disclosure of mining companies in Indonesia. The larger the size of the company, the more pressure and spotlight the company get from the community and the government. So, the company will increasingly show concern for the environment. Larger size companies will also carry out and disclose CSR to gain legitimacy from the community and to reduce the agency costs. Profitability does not affect CSR disclosure of mining compa- 
nies in Indonesia. the profit generated will mainly be used to maximize the company's operations to bring more profit. Leverage, also, does not have an effect towards CSR disclosure of mining companies in Indonesia. Loans carried about by the company will be used to support the financing of the company's internal activities to add value and to improve the product quality. In addition, the company must carry out CSR activities and disclose them as a form of compliance with regulations set by the government. Managerial ownership has a negative effect on the number of CSR disclosure. Managers who own more shares in the company will tend to maximize their role as the owner of the company, namely, to gain profits by reducing the costs, including the cost of CSR activities and disclosure. On the other hand, managers who own less shares will maximize their role as a company manager, namely, by maximizing the company's potential to gain a good image in the community by doing CSR and disclose every each of them.

\section{Implication}

Theoretical Implications. Previous researches that discuss the influence of company size, profitability, leverage and management ownership towards the level of CSR disclosure is still inconclusive. This particular study shows that company size has a positive effect towards the level of CSR disclosure, profitability and leverage does to have any effect towards CSR disclosure, and management ownership has a negative effect on the level of CSR disclosure. The results of this study add to the understanding that has been around from previous studies and other studies in the field of management accounting and CSR. Empirical Implications. This study can provide empirical implication for several parties, including:

\section{a. For the company}

This study found that high management ownership can cause conflicts of interest between the role of managers as company owners and company management, so that decisions taken by managers become biased. Therefore, companies need to pay attention to the proportion of share ownership to minimize conflicts 
of interest. In addition, the company should pay attention of their CSR disclosure when the percentage of management ownership is high, so that the level of CSR disclosure does not fall off. Based on the result of the study, it can also be seen that the company needs to maximize the size of the company represented by its total assets in order to increase the level of CSR disclosure.

\section{b. For the creditors and investors}

The research informs that the size of a company, management ownership as well as concern and sensitivity of the company to the surrounding environment are the main factors in company's CSR activities and the high level of company's CSR disclosure. This research also provides information to creditors and investors who have long-term goals so that they can pay more attention to several factors related to the company, including the company size, management ownership, and concern and sensitivity of the company to the surrounding environment. For creditors and investors who have short term goals, it is expected that hey pay attention to the level of company's profitability and leverage. this is intended so that creditors and investors do not make false decision in making credit and investment choices.

\section{c. For the government}

The research findings provide two main information. First, for the government to carry out the oversight/ observation function related to implementing CSR regulations. Second, for the government to standardize the breadth and obligation in reporting CSR activities. From the findings, it can be seen that the implementation of CSR activities is not as effective and not on its maximum level. This is shown by the low number of CSR disclosure indexes by mining companies in Indonesia. it can also be interpreted that the company carries out CSR activities and discloses it only to fulfil its obligation in complying with regulation made by the government. The low number of CSR disclosure indexes can provide information or signals for the government to be able to continue to encourage mining companies to improve CSR activities and their disclosure through standardization of CSR disclosure. 


\section{REFERENCES}

Agustina, W., Yuniarta, G. A., \& Sinarwati, N. K. (2015). Pengaruh Intellectual Capital, Corporate Social Responsibility dan Good Corporate Governance Terhadap Kinerja Keuangan (Studi Kasus pada Perusahaan BUMN yang Terdaftar di Bursa Efek Indonesia pada Tahun 2011-2013). e-Journal S1 Ak Universitas Pendidikan Ganesha Jurusan Akuntansi Program S1.

Antara. (2018). Tumpahan Minyak di Balikpapan, Pertamina Bantah Lalai.

Retrieved from Tempo.co: https://bisnis.tempo.co/read/1076798/tumpahanminyak-di-balikpapan-pertamina-bantah-lalai.

Bangkapos. (2012). 70 Persen Kerusakan Lingkungan akibat Tambang. Retrieved from Bangkapos.com: http://bangka.tribunnews.com/2012/09/28/70-persenkerusakan-lingkungan-akibat-tambang.

Carroll, A. B. (2015). Corporate Social Responsibility: The Centerpiece of Competing And Complementary Frameworks. Organizational Dynamics, 87-96.

Dewi, S. S. \& Priyadi, M. P. (2013). Pengaruh Karakteristik Perusahaan Terhadap Corporate Social Responsibility Disclosure pada Perusahaan Manufaktur yang Terdaftar di BEI. Jurnal Ilmu \& Riset Akuntansi, 2(3), 1-20.

Dianjiwa, V. (2015). 2015, Tahun Jebloknya Industri Batu Bara. Retrieved from Tambang.co.id: https://www.tambang.co.id/7179-7179/.

Gewati, M. (2016). Industri Tambang Global dan Nasional Ada di Ujung Tanduk? Retrieved from Kompas.com: https://ekonomi.kompas.com/read/ 2016/12/15/124400126/industri.tambang.global.dan

.nasional.ada.di.ujung.tanduk.

Hawawini, G. \& Viallet, C. (2007). Finance for Executives: Managing for Value Creation.

United States of America: South-Western Cengage Learning.

Ihsanuddin. (2018). Minyak Tumpah di Balikpapan, Pertamina Kehilangan 200.000 Barel per Hari. Retrieved from Kompas.com: https://nasional.kompas.com/ read/2018/04/05/21072471/minyak-tumpah-di-balikpapan-pertamina-kehilangan-200000-barel-per-hari.

Istifaroh, A. \& Subardjo, A. (2017). Faktor-Faktor yang Memengaruhi Pengungkapan Corporate Social Responsibility. Jurnal Ilmu dan Riset Akuntansi, 119. 
Manurung, E., \& Muid, D. (2015). Pengaruh Karakteristik Perusahaan terhadap Pengungkapan Tanggung Jawab Sosial. Diponegoro Journal of Accounting, 1-9.

Maulana, F. \& Yuyetta, E. N. (2014). Pengaruh Karakteristik Perusahaan terhadap Pengungkapan Corporate Social Responsibility (CSR). Diponegoro Journal of Accounting, 1-14.

Nazir, M. (2005). Metode Penelitian. Bogor: Penerbit Ghalia Indonesia.

Oktariani, W. (2013). Pengaruh Kepemilikan Publik, Ukuran Dewan Komisaris, Profitabilitas, dan Umur Perusahaan terhadap Pengungkapan Tanggung Jawab Sosial Perusahaan. Jurnal Ilmiah Wahana Akuntansi, 8(2), 100-117. Primadhyta, S. (2018). Pertamina Selidiki Penyebab Pipa Balikpapan Bocor. Retrieved from CNN Indonesia: https:/www.cnnindonesia.com/ekonomi/ 20180404191409-85-288300/pertamina-selidiki-penyebab-pipa-balikpapanbocor.

Ramadhani, M. F. (2018). Tragedi Tumpahan Minyak di Balikpapan: Kasus Pencemaran Teluk Balikpapan, Polda Kaltim Periksa 9 Orang Pegawai Pertamina. Retrieved from TribunKaltim.co: http://kaltim.tribunnews.com/ 2018/04/09/kasus-pencemaran-teluk-balikpapan-polda-kaltim-periksa-9-orang-pegawai-pertamina.

Rembeth, D. (2016). PwC: Tahun 2015 Sebagai Tahun Terburuk bagi Sektor Pertambangan. Retrieved from PWC: https://www.pwc.com/id/en/mediacentre/pwc-in-news/2016/indonesian/pwc-tahun-2015-sebagai-tahunterburuk-bagi-sektor- pertambangan.html.

Sembiring, E. R. (2005). Karakteristik Perusahaan dan Pengungkapan Tanggung Jawab Sosial: Studi Empiris pada Perusahaan yang Tercatat di Bursa Efek Jakarta. Simposium Nasional Akuntansi VIII, 379-395.

Sriayu, G. P. \& Mimba, S. N. (2013). Pengaruh Karakteristik Perusahaan terhadap Corporate Social Responsibility Disclosure. E-Jurnal Akuntansi Universitas Udayana, 326-344.

Subiantoro, O. H. \& Mildawati, T. (2015). Pengaruh Karakteristik Perusahaan terhadap Pengungkapan Corporate Social Responsibility. Jurnal Ilmu \& Riset Akuntansi, 1-21.

Vogel, D. (2005). The Market for Virtue: The Potential and Limits of Corporate Social Responsibility. Washington DC: Brookings Institution Press. 
Journal of Accounting, Entrepreneurship, and Financial Technology

Volume 01, Number 01, October 2019

Wang, J., Song, L., \& Yao, S. (2013). The Determinants of Corporate Social Responsibility Disclosure: Evidence from China. The Journal of Applied Business Research, 1833-1848.

Wasis. (1997). Pengantar Ekonomi Perusahaan. Bandung: PT Alumni.

Yuliawati, R. \& Sukirman. (2015). Faktor-Faktor yang Memengaruhi Pengungkapan Corporate Social Responsibility. Accounting Analysis Journal, 1-9. 